\author{
JOACHIM ŚLIWA \\ UNIWERSYTET JAGIELLOŃSKI
}

\title{
NICOLAS TOURTECHOT ZWANY GRANGER (OKOLO 1680 - 1737) I ODKRYWANIE GÓRNEGO EGIPTU
}

\section{SUMMARY: Nicolas Tourtechot Known as Granger (ca. 1680 - 1737) and The Discovery of Upper Egypt}

A French doctor, who travelled up of the Nile in the first half of 1731, wrote Relation du voyage fait en Égypte [...], published in 1745 (soon his book was published in English and German). Tourtechot, during his transit to the south, noted and described several monuments. He realized that in Luxor and Karnak he was seeing the remains of the ancient Thebes, although he presumably never reached the west bank of the Nile, and the information referring to the Theban necropolis was drawn by him from indirect sources. He intended to go further to the south, but in Edfu local riots made him go back. In his report Tourtechot put Greek inscriptions which he had found in several places (Qus, Esna, Akhmim, Sheikh Abade); in the following years these inscriptions were included in specialist studies. Tourtechot's information about Coptic monasteries which he had visited during his voyage are also considered important (he managed to visit the monasteries of St. Anthony and St. Paul on the Red Sea, which were difficult to reach). He wrote a great deal about the details of everyday life, nature and customs. Dangerous moments and specific curiosities described by Tourtechot make his simple and unpretentious writing more vivid and appealing for the reader. Tourtechot's work constitutes an important part in the history of studies on the art and topography of ancient Egypt.

Egipt od wieków budził żywe zainteresowanie nowożytnej Europy, choć bezpośredni dostęp do kraju nad Nilem nie był zbyt łatwy. Do rzadkości należały więc początkowo w miarę wyczerpujące i godne 
zaufania relacje, poszerzające zasób rzetelnej wiedzy o tym kraju. W znacznym stopniu opierano się nadal na wiadomościach czerpanych z przekazów takich autorów starożytnych jak Herodot, Strabon czy Diodor. $\mathrm{Z}$ wolna sytuacja ulegała jednak zmianie, zacieśniały się bowiem więzy handlowe z Egiptem, znaczne postępy czyniły też zgromadzenia misyjne aktywnie działające nad Nilem (franciszkanie, dominikanie, jezuici). Duże znaczenie odgrywał ruch pielgrzymkowy, kierując coraz większe liczby wiernych do Ziemi Świętej, docierających jednak drogą morską najpierw do Aleksandrii, a następnie dopiero do miejsc świętych w Palestynie ${ }^{1}$. Z tego też względu egipska Delta wraz z Aleksandrią i Kairem znane były europejskim podróżnym znacznie lepiej niż Górny Egipt, a więc obszary położone dalej w kierunku południowym. Opisywano zespół Wielkich Piramid w Gizie oraz wspaniałości muzułmańskiego Kairu, najczęściej jednak nie domyślano się nawet monumentalnych budowli z czasów faraonów na terenie Górnego Egiptu. Śmiało można powiedzieć, że ich odkrycie nastąpiło dopiero wówczas, gdy z Kairu na południe wyruszyły francuskie oddziały wraz z towarzyszącymi im badaczami, członkami ekspedycji wojskowej (17981801), która znalazła się tutaj z inicjatywy Napoleona Bonapartego ${ }^{2}$. Ogromne znaczenie miała też stworzona wówczas dokumentacja opisowa i rysunkowa, wkrótce wydana drukiem, co dało asumpt do stwierdzenia, iż Egipt stał się wówczas „najlepiej opisanym krajem świata”’.

Próby dotarcia dalej na południe, na tereny Górnego Egiptu, podejmowano oczywiście już wcześniej. Jednym z istotniejszych celów było odnalezienie Teb, dawnej stolicy egipskiego imperium ${ }^{4}$. Wśród podróżników zmierzających w tym kierunku wspomnieć należy Johanna Michaela Wanslebena (1635-1679), dominikanina, który w Egipcie

$1 \quad$ Doskonały przykład stanowić może pielgrzymka Mikołaja Krzysztofa Radziwiłła „Sierotki” i sporządzona przez niego ciekawa relacja; zob. Radziwiłł 1962.

$2 \quad$ Por. m.in. następujące opracowania: Strathern 2009; Bret 2002; Solé 2001.

3 Wyniki prac dokumentacyjnych i zebrane materiały ukazały się wkrótce w wielotomowym dziele pt. Description de l'Égypte, Paryż 1809-1822, stanowiącym doskonałe kompendium dotyczące zarówno przeszłości kraju, jak i jego geografii, warunków naturalnych oraz flory i fauny. Duże znaczenie miała też relacja Dominique Vivant Denona, uczestnika wyprawy napoleońskiej; zob. Denon 1802.

$4 \quad$ Mamy tu do czynienia z pewnym paradoksem, egipskie Teby zostały bowiem prawidłowo zlokalizowane już na odpowiedniej mapie atlasu Theatrum orbis terrarum Abrahama Orteliusza (edycja z roku 1584). 
przebywał w latach 1663-1664 i następnie od roku 16715. W trakcie jednej ze swych podróży dotarł aż do Girgi, choć w jego zamierzeniach znajdowały się obszary położone jeszcze dalej ${ }^{6}$. Wansleben uważał się zresztą za odkrywcę Teb, za ten ośrodek uznał bowiem dość okazałe ruiny rzymskiego Antinooupolis.

Bliżej właściwego rozwiązania znaleźli się w tym czasie dwaj francuscy kapucyni, ojcowie Protazy i Franciszek, którzy w Górnym Egipcie przebywali w roku $1668^{7}$. W ich zapiskach znajdujemy bowiem wzmiankę o „miejscu mumii zwanym Biban el Melouc” oraz wiadomość, że „tuż nad Nilem oglądać można dwa wielkie kamienne idole siedzące na tronach". Bez wątpienia jest to informacja o nekropoli tebańskiej (Dolina Królów) i tzw. Kolosach Memnona. Nie zdołano jednak wówczas tych wiadomości odpowiednio wykorzystać w zestawieniu z przekazami Diodora i Strabona ${ }^{9}$.

Aż do rejonu I katarakty, a więc znacznie dalej na południe, dotarł kilka lat później Paul Lucas (1664-1737), francuski kupiec i antykwariusz $^{10}$. Płynąc Nilem, nie zatrzymał się jednak na wysokości Teb ze względu na niebezpieczeństwo spowodowane lokalnymi zamieszkami. Zaznaczył jednak, iż przepływając w pobliżu, zdołał zobaczyć

\footnotetext{
$5 \quad$ Zob. Wansleben 1677 (także przekład na język angielski, 1678). Johann Michael Wansleben był Niemcem w służbie francuskiej (z tego względu jego nazwisko najczęściej występuje w formie „Vansleb”). W trakcie swej podróży Wansleben zgromadził na zlecenie ministra J.B Colberta m.in. sporą liczbę koptyjskich manuskryptów dla Biblioteki Królewskiej w Paryżu; zlecono mu również gromadzenie starożytnych monet i medali, posągów i reliefów oraz kopiowanie starożytnych inskrypcji.

6 Do szybszego powrotu do Kairu zmusiło go zagrożenie ze strony ludności miejscowej widzącej w nim poszukiwacza skarbów, które chciał im - ich prawowitym właścicielom - zagrabić. Tego rodzaju podejrzeń i wynikających z tego zagrożeń doświadczali niejednokrotnie i inni podróżnicy oraz badacze, nawet jeszcze w XX wieku.

Ich Relation du voyage du Zaid ou de la Thebaide fait en 1668 par les capucins missionaires en Égypte uwzględnił w swym dziele Melchisédec Thévenot (Thévenot 1681). Zob. Greener 1966: 60-61.

8 We wspomnianej relacji mowa też o monumentalnych ruinach na obszarze dzisiejszego Luksoru i Karnaku z opisami alei sfinksów oraz monumentalnych pylonów i kolumn sali hypostylowej (por. Greener 1966: 60).

9 Por. Greener 1966: 61.

10 Por. Lucas 1704 oraz Lucas 1720.
} 
„ogromne pałace, wspaniałe świątynie, obeliski oraz zdumiewającą ilość potężnych kolumn nadal stojących na swoim miejscu"11.

W tym samym czasie (od roku 1708) działał w Egipcie również francuski jezuita Claude Sicard (1667-1726), który jako misjonarz podjął dzieło nawracania Koptów na łono Kościoła rzymskiego. Odbył on parokrotnie podróże do Górnego Egiptu (znał doskonale język arabski), docierając również do Asuanu; opisał m.in. pozostałości starożytnych budowli w Aszmunein/Hermopolis magna ${ }^{12}$, Antinooupolis, Kom Ombo oraz na wyspach Philae i Elefantynie ${ }^{13}$. Bez wątpienia ojciec Sicard zidentyfikował już prawidłowo i świadomie ruiny Karnaku i Luksoru jako pozostałości dawnych Teb. Skonfrontował też przekazy Strabona i Diodora z oglądanymi przez siebie Kolosami Memnona i ruinami Ramesseum, a także z grobami Doliny Królów. W Bibliotece Narodowej w Paryżu przechowywana jest doskonała mapa Egiptu sporządzona przez ojca Sicarda.

Ciekawą relację, opatrzoną rycinami, opublikował wkrótce Richard Pococke (1704-1765), angielski duchowny, który przebywał w Egipcie w latach 1737-173914. Płynąc Nilem, dotarł do Asuanu, odwiedzając m.in. Denderę, Teby (il. 1) i Armant. Jeszcze dalej na południe dotarł w tym czasie (1738) Frederik Ludwig Norden (1708-1742), duński żeglarz, podróżnik i artysta ${ }^{15}$, który dopłynął aż do Derr w Nubii. On również zostawił wartościową relację opatrzoną dobrymi rycinami (il. 2). Nie można w tym miejscu pominąć także szkockiego orientalisty Jamesa Bruce’a (1730-1794), który w trakcie swej dłuższej podróży

11 Dotarł jednak do pobliskiego Armant (istotne są wieści, które przekazał na temat oglądanych tu budowli, gdyż uległy one w następnych stuleciach poważnym zniszczeniom); wcześniej zatrzymał się w Denderze, poświęcając jej budowlom szeroki opis, plan oraz rysunek świątynnego portyku).

12 Opisane przez niego budowle w znacznej części nie dotrwały do naszych czasów.

13 Jego relacje z zachowanych rękopisów opublikowali Serge Sauneron i Maurice Martin: Sicard 1982. Na uwagę zasługuje mapa Sicarda jako pionierskie przedsięwzięcie, obejmująca dolinę Nilu aż po Asuan. Sicard padł ofiarą zarazy panującej w Kairze w roku 1726.

14 Pococke 1743-1745. W trakcie swych podróży przebywał w Egipcie dwukrotnie: od października 1737 do marca 1738 oraz od grudnia 1738 do lipca 1739.

15 Norden 1755. 
znalazł się w Egipcie w czerwcu roku $1768^{16}$. Dotarł on również do Teb; był w Luksorze i Karnaku oraz w Dolinie Królów. Tu jego uwagę zwrócił jeden z grobowców, który oczyścił i sporządził jego dokumentację. Grobowiec ten zaczęto wkrótce określać jako „Grobowiec Bruce’a”, nim ustalono, iż było to miejsce pochówku Ramzesa III (KV 11).

W zachowanych sprawozdaniach $\mathrm{z}$ orientalnych podróży i pielgrzymek, których autorzy nie zawsze dysponowali odpowiednim talentem narracyjnym i zmysłem obserwacji, oprócz zabytków i informacji historycznych znajdujemy częstokroć także spostrzeżenia o charakterze ciekawostek lokalnych czy wręcz anegdot. Z punktu widzenia odbiorcy pełniły one doniosłą funkcję, podkreślając dodatkowo egzotykę i autentyzm relacji oraz pozwalając bez większego dystansu zbliżyć się do opisywanych wydarzeń, co z kolei znacznie poszerzało krąg bardziej zainteresowanych czytelników. Obecnie najistotniejsze są dla nas zachowane w owych relacjach opisy zabytków starożytnych, ich ówczesny stan oraz opinie wypowiadane przez ich odkrywców.

Wśród wymienionych podróżników specjalne miejsce zajmuje francuski lekarz i spostrzegawczy przyrodnik Nicolas Tourtechot, znany później głównie pod pseudonimem „Granger”17. Jego pobyt w Egipcie przypadł na lata tuż po śmierci ojca Sicarda (1726), a przed podróżami Richarda Pococke'a (1737-1739). Bez wątpienia należy on do tej nielicznej grupy podróżników, którzy swymi rzeczowymi relacjami potrafili zainteresować współczesnych. Mimo pewnych potknięć i nieścisłości uwagi Tourtechota pozwoliły rozwikłać szereg zagadnień, a greckie inskrypcje skopiowane wprawdzie w dość nieudolny sposób stały się przedmiotem szerszych dyskusji i studiów, które znalazły się u początków epigrafiki jako wyspecjalizowanej dyscypliny nauk filologicznych.

Nicolas Tourtechot urodził się około roku 1680 w Dijon (Burgundia $)^{18}$. Jako medyk zyskał uznanie, walcząc w roku $1721 \mathrm{z}$ epidemią

16 Bruce 1790. Bruce podróżował razem z włoskim architektem i rysownikiem Luigim Baluganim (1737-1771), który zmarł w trakcie wyprawy.

17 Nie zdołano ustalić, z jakich względów zaczął posługiwać się jedynie tym drugim, przybranym nazwiskiem (nie potrafił tego wyjaśnić również wydawca jego relacji w roku 1745, por. niżej, przypis 20).

18 Szczegóły jego biografii nie są zbyt obfite; część z nich pochodzi ze wstępu, którym relację z jego podróży opatrzył wydawca (por. niżej, przypis 20). Zob. Diction- 
zarazy, która panowała wówczas w Marsylii i Tulonie. Wkrótce potem objął stanowisko naczelnego lekarza w szpitalu hiszpańskich trynitarzy w Tunisie. Znalazł się tam dzięki pośrednictwu swego przyjaciela Jean Pierre'a Pignona, pełniącego wówczas urząd francuskiego konsula w Tunisie. W roku 1724 zrezygnował z pracy w szpitalu, nadal jednak pozostał w tym mieście.

W roku 1728 Tourtechot wrócił do Francji, by zająć się studiami przyrodniczymi. Wkrótce jednak znalazł się ponownie na Bliskim Wschodzie, znowu towarzysząc Pignonowi, który tym razem objął analogiczną placówkę dyplomatyczną w Kairze. W trakcie pobytu w Egipcie (lipiec 1730 - marzec 1732), zainteresowany przyrodą i starożytnościami kraju, Tourtechot dotarł wzdłuż Nilu aż do Edfu.

Do Francji powrócił Tourtechot w roku 1732, lecz nie był to koniec jego orientalnych wojaży. Otrzymał bowiem kolejne zadanie, tym razem poparte zleceniem Ludwika XV, by możliwie dokładnie rozpoznać warunki przyrodnicze i geografię Bliskiego Wschodu. Z Francji wyruszył w roku 1733 (tym razem także wraz z Pignonem) i z Cyrenajki przez Kretę dotarł ponownie do Egiptu. Następnie udał się na Cypr, do Palestyny i Syrii ${ }^{19}$. Zmarł nagle 15 lutego 1737 roku w drodze powrotnej z Isfahanu (Persja), podczas pobytu w pobliżu Basry w Mezopotamii.

Relacja Tourtechota z jego pierwszej podróży egipskiej wprawdzie ocalała, lecz wydana została drukiem dopiero w kilka lat później (1745), już po jego śmierci, jako Relation du voyage fait en Égypte, par le Sieur Granger, en l'année 1730. Ou l'on voit ce qu'il y a de plus remarquable, particulièrement sur l'histore naturelle ${ }^{20}$ (il. 3). Wzbudziła

naire de biographie française, 1985, szp. 1018 (A. Tétry); Bierbrier 2012: 220.

19 Z jego zachowanych w rękopisie notatek podróżnych wspomnieć należy opis Palmyry, wydany przez J. B. Chabota (Chabot 1897).

20 Paris 1745 , (z aprobatą i przyzwoleniem królewskim wydał Jacques Vincent), ss. 262. Dostępny jest także reprint tej edycji z roku 2012 (Nabu Press). Zaznaczyć należy, iż rok „1730” podany w tytule, nie odpowiada rzeczywistości (jest to jedynie rok przybycia Tourtechota do Egiptu), gdyż podróż na południe miała miejsce dopiero w pierwszej połowie roku następnego (zob. niżej). Jak się obecnie przypuszcza, wydawca, bez podania źródła, włączył do tekstu także niepublikowane fragmenty listów Claude'a Sicarda. Stwierdzili to Florimond Lamy i Marie-Cécile Bruwier: Lamy, Bruwier 2005: 180-184. 
ona od razu ogromne zainteresowanie, rychło też przygotowane zostały jej edycje w języku niemieckim i angielskim ${ }^{21}$.

Tourtechot wysiadł na brzeg w Aleksandrii 18 lipca 1730 roku, a do Kairu dotarł 6 sierpnia. Natomiast w swą podróż badawczą do Górnego Egiptu wyruszył 29 stycznia 1731 roku; w wyprawie towarzyszył mu włoski misjonarz reprezentujący watykańską Congregatio de propaganda fide, kilku Koptów oraz czterech tureckich janczarów jako ochrona (Tourtechot 1745: 28-30).

Z ważniejszych miejsc, do których dotarł Tourtechot, wymienimy tylko niektóre, odpowiednio do znaczenia jego obserwacji i przekazanych opisów. 23 lutego Tourtechot dotarł do miejscowości Madfoune (,Miasto zasypane”), obecnie el-Araba el-Madfuna, z zespołem architektonicznym znanym jako Abydos (Tourtechot 1745: 37-40); jest on położony w znacznej odległości od Nilu, na jego zachodnim brzegu ${ }^{22}$. Od Kairu dzieliła wędrowca już odległość około 600 kilometrów. Zwrócił tu uwagę na pozostałości starożytnego zespołu architektonicznego, które określił jako „świątynię Birbé” i na swój sposób dość starannie opisał (Tourtechot 1745: 38-39) 23. Mimo iż w roku 1718 dotarł tu już ojciec Sicard, właśnie Tourtechota można uznać za właściwego odkrywcę tego odwiedzanego dziś powszechnie przez turystów sanktuarium Ozyrysa ${ }^{24}$ oraz pozostałości świątyń Ramzesa I i II, a także świątyni grobowej Setiego ${ }^{25}$. Do odsłaniania tych budowli, niemal całkowicie zasypanych pustynnym piaskiem, przystąpił dopiero Auguste Mariette w roku 1857.

\footnotetext{
21 Por. Tourtechot 1751: 307-428 oraz Tourtechot 1773.

22 Zob. także Lamy, Bruwier 2005: 181. Starożytna nazwa tego ośrodka brzmiała Abdżu; znajdują się tu pozostałości osadnictwa i cmentarzysk od epoki predynastycznej po czasy chrześcijańskie. Tu zaczyna się ważny szlak karawanowy wiodący do Oazy Dachla.

23 Odnotował także obecność dobrze zachowanych ruin (Tourtechot 1745: 40), przez Arabów zwanych Chounait Elzebibé (Szunet ez-Zebib, „Suszarnia winogron”), obecnie identyfikowanych jako okręg grobowy Chasechemui, jednego z władców II dynastii.

24 Tzw. Ozyrejon, cenotaf Ozyrysa, poczynając od okresu Średniego Państwa jeden z najważniejszych ośrodków kultowych w Egipcie.

25 Na ich ścianach znajdują się ważne przekazy historyczne: na ścianach świątyni Setiego I (przez starożytnych określanej mianem „Memnonium”) wykuto listę jego poprzedników, natomiast na pylonach świątyni Ramzesa II tzw. epos o bitwie pod Kadesz.
} 
W parę dni później dotarł Tourtechot wraz ze swą grupką do Dendery; opisane przez niego świątynie jako przybytki Izydy i Wenus (Tourtechot 1745: 41-50) to budowle poświęcone Hathor i Izydzie, pochodzące z czasów ptolemejskich i rzymskich ${ }^{26}$. Jedna z nich była przysypana całkowicie gruzami i piaskiem.

Gdy Tourtechot dopłynął do Luksoru, wiedział już, że „wioska ta wzniesiona została na ruinach Teb"; oraz - jak pisze dalej - iż ,to starożytne miasto tak niegdyś wspaniałe ze względu na swe budowle, to dziś jedynie sterta kamieni" (Tourtechot 1745: 54). W pobliżu jednej z „bram” (tj. pylonu) wymienia dwa obeliski oraz dwa kolosalne posągi (jego zdaniem „kobiece”) z pięknego czarnego marmuru, w połowie przysypane; tu rozpoczynała się też wiejska ulica prowadząca do sali z podwójnym szeregiem kolumn i pozostałościami stropu (Tourtechot 1745: 54-56) $)^{27}$. Od tego kompleksu architektonicznego aleja sfinksów z baranimi głowami wiodła do ,zamku” oddalonego o całą milę, tzn. do zespołu świątynnego w Karnaku (Tourtechot 1745: 56-61) ${ }^{28}$. W swym opisie Tourtechot zwrócił tu uwagę na partie lepiej zachowane, w tym m.in. na salę hypostylową, pomieszczenie nazwane przez niego „salonem”, a także „basen” (święte jezioro) wyłożony marmurem, w którym woda znajduje się przez cały rok. Nieraz jednak trudno odtworzyć jego marszrutę na terenie obu zespołów architektonicznych, których opisy przypuszczalnie w fazie redakcyjnej (już bez jego udziału) nie zostały odpowiednio uporządkowane.

Niestety, również inne jego opisy pozbawione są bardziej ugruntowanego ładu topograficznego, z czego m.in. wnosić można, iż prawdopodobnie nie dotarł na zachodni brzeg Nilu i powtarzał jedynie

26 Dendera (eg. Junet, gr. Tantere/Tentyris) to ważny ośrodek kultowy bogini Hathor. Jej doskonale zachowana świątynia z czasów ptolemejskich budziła zachwyt i zainteresowanie wielu podróżnych (w pełni odsłonięta została przez A. Mariette'a dopiero w roku 1859). Strop o dekoracji astronomicznej pochodzący z jednej z jej kaplic przewieziony został do paryskiego Luwru w roku 1823.

27 Można tu rozpoznać pylon wzniesiony przez Ramzesa II, poprzedzający kolejne konstrukcje świątyni Amona. Ze wspomnianych obelisków Ramzesa II na miejscu pozostał do dziś tylko jeden, gdyż drugi wywieziony został w roku 1831 do Paryża i ustawiony uroczyście w roku 1834 na Place de la Concorde. Oczywiście kolosalne posągi ustawione przed pylonem to wizerunki Ramzesa II. Natomiast podwójny szereg kolumn (2 x 7) to kolumnada z czasów Amenofisa III - Horemhaba.

28 Zob. także Lamy, Bruwier 2005: 181-182. 
informacje zasłyszane od tubylców lub czerpał z opisów swych poprzedników ${ }^{29}$. Brak w jego relacji najmniejszej nawet wzmianki o konieczności udania się na drugi brzeg rzeki, by dotrzeć do Doliny Królów, Medinet Habu czy do Kolosów Memnona ${ }^{30}$. W jednym z posągów oglądanych w Karnaku domyśla się Memnona (Tourtechot 1745: 6263), natomiast opis obu kolosalnych posągów Amenofisa III, w tym właściwego Memnona, umieszcza w innym miejscu (Tourtechot 1745: 64-65).

Z Teb udał się Tourtechot do pobliskiego Armant/Hermontis (Tourtechot 1745: 70), a następnie do Esny, niewłaściwie identyfikowanej przez niego z Asuanem (Tourtechot 1745: 72-74). Wreszcie z Esny dotarł Tourtechot do Edfu ${ }^{31}$, odnotowując kamieniołom na wschodnim brzegu Nilu (z widocznymi niewykończonymi kolumnami i blokami), a następnie na brzegu zachodnim ptolemejską świątynię Horusa, jedną z najlepiej zachowanych budowli egipskich (Tourtechot 1745: 76-78). Jak pisze, „wieś Utfou zbudowana jest na ruinach Apollinopolis; widoczne są ruiny świątyni, lecz nie można do niej wejść, gdyż jest pełna ziemi i zwalisk" (Tourtechot 1745: 77).

Niestety, mimo niezbyt już wielkiej odległości do Asuanu, Tourtechot nie wyruszył już dalej na południe. Poczynając od Edfu, pod koniec marca 1731 roku rozpoczęła się jego droga powrotna. Jak sam stwierdził: „Walki, które niemal codziennie toczyły się między Arabami, powstrzymały mnie" (Tourtechot 1745: 78). Po powrocie do Kairu, w którym spędził dwa miesiące, mimo panującej zarazy pracowicie zwiedzał i opisywał miasto, jego meczety i minarety, łaźnie publiczne oraz chrześcijańskie klasztory (Tourtechot 1745: 132-146). W dniu 27 lipca, gdy zwolna wygasała już epidemia w Kairze, wyruszył Tourtechot do Oazy Fajum, dając ciekawy opis całej prowincji (Tourtechot

\footnotetext{
29 Sądzą tak m.in. Lamy, Bruwier 2005: 182, 184.

30 Nawet odległości oblicza poczynając od Luksoru albo Karnaku, np. Medinet Habu znajduje się według niego o milę od Karnaku, bez konieczności udania się na zachodni brzeg Nilu (por. Tourtechot 1745: 65).

31 Edfu (eg. Dżeb, gr. Apollonospolis megale, łac. Apollinopolis magna) to stary ośrodek kultu Horusa. Bierze tu początek także jeden z ważnych szlaków karawanowych, wiodących przez Pustynię Arabską nad Morze Czerwone. Edfu odegrało istotną rolę w dziejach polskiej egiptologii, gdyż tu w latach 1937-1939 prowadzone były wspólne, polsko-francuskie badania wykopaliskowe.
} 
1745: 147-166) ${ }^{32}$. W jego relacji znajdują się również opisy Aleksandrii, Suezu i takich miast Delty jak Rosetta i Damietta.

Tourtechot jako człowiek wykształcony zwrócił parokrotnie uwagę na inskrypcje greckie, na które natrafił w trakcie swej wędrówki. Zdawał sobie sprawę z ich znaczenia, niektóre z nich potrafił w pełni odczytać, inne natomiast - gorzej zachowane - jedynie odnotowywał. Własnoręcznie sporządzone kopie inskrypcji włączył do swej relacji, dostarczając w ten sposób ważny materiał dla następnych pokoleń badaczy i przyczyniając się do rozwoju epigrafiki. Inskrypcje, którymi wówczas zainteresował się Tourtechot, w następnym stuleciu wykorzystał w swych studiach m.in. Jean Antoine Letronne (1787-1848), uważany powszechnie za twórcę nowoczesnej epigrafiki ${ }^{33}$. W niewiele lat później inskrypcje te włączone zostały do odpowiedniego tomu Corpus Inscriptionum Graecarum, przedsięwzięcia któremu patronowała Pruska Akademia $\mathrm{Nauk}^{34}$. Inskrypcjami greckimi uwzględnionymi w relacji Tourtechota zainteresował się w swoim czasie (1909) także Tadeusz Smoleński (1884-1909), pionier polskiej egiptologii ${ }^{35}$.

Pierwszą z omawianych inskrypcji odnotował i skopiował Tourtechot „taką, jaka jest” w Qus/Apollinopolis parva, skąd udał się już bezpośrednio do Teb (Tourtechot 1745: 53-54) ${ }^{36}$. Jest to tekst dedykacji z czasów wspólnego panowania Ptolemeusza IX Sotera II i jego matki Kleopatry III (116-107 p.n.e.), umieszczonej niegdyś na propylonie miejscowej świątyni. Kopia sporządzona przez Tourtechota (il. 4) nie

32 Na jednej z kolumn zrujnowanego ,,pałacu Karona” odnalazł nazwisko Paula Lucasa, który dotarł tu kilka lat wcześniej (Tourtechot 1745: 152).

33 Letronne 1842-1848.

34 Franzius 1853: 281-458.

35 Smoleński 1910: 27-33 (tekst ten, złożony do druku w maju 1909 roku, ukazał się już po śmierci autora). Zob. także przedruk, w: Śliwa, Zinkow (oprac.) 2010: 121-126. Jak zaznaczył Smoleński w swej publikacji, gdyby tekst relacji podróżnej Tourtechota ukazał się jeszcze za jego życia, umieszczone w nim inskrypcje byłyby zapewne opracowane staranniej, mimo iż autor nie był hellenistą. Od wydawcy tekstu bowiem, jak wiemy, zależy w takiej sytuacji bardzo dużo. Wprawdzie, jak wynika ze wstępu poprzedzającego Relation (Tourtechot 1745: VIII-IX), znane były już wówczas (1745) zarzuty wysuwane przez filologów, ale ostatecznie wydawca postanowił pozostawić tekst w takiej formie, w jakiej dotarł do niego rękopis.

36 Tourtechot niewłaściwie identyfikował Qus jako Antenopolis (Antinooupolis), na co zwrócono uwagę już w późniejszych komentarzach (por. przypis następny). 
jest doskonała, lecz mimo to pozwalała na odczytanie i zrozumienie tekstu i uwzględniona została przez kolejnych wydawców ${ }^{37}$.

W trakcie pobytu w okolicach Esny/Latopolis, zwiedzając klasztor Męczenników (Deir asz-Szuhada) ${ }^{38}$, zauważył Tourtechot pięć krótkich tekstów wyrytych na blokach wbudowanych w mur kościelnego dziedzińca (Tourtechot 1745: 74-75) ${ }^{39}$. Nie wszystkie z nich były jednakowo dobrze zachowane, podróżnemu kłopot sprawiały także znaki alfabetu koptyjskiego. Odnotowane wówczas teksty, to w głównej mierze fragmenty stel nagrobnych z imionami zmarłych (w tym m.in. „Wiktora” oraz „Paulosa”).

Na tekst nieco dłuższy i bardziej skomplikowany (a także gorzej zachowany) natrafił nasz wędrowiec w Achmim/Panopolis (Tourtechot 1745: 85). Pełny tekst, jego właściwe znaczenie i interpretację ustalili dopiero jego późniejsi wydawcy (tytulatura cesarza Trajana, 98-117 n.e.); został on znaleziony w ruinach świątyni z czasów Ptolemeusza IV Filopatora (221-205 p.n.e. $)^{40}$. Tourtechot podał również ciekawą informację natury etnograficznej dotyczącą tej inskrypcji, a właściwie kamiennego bloku, na którym ów tekst został wykuty. Zgodnie z jego przekazem „bezpłodne kobiety z Achmim, aby odzyskać możność rodzenia, na kamień ów oddają mocz" (Tourtechot 1745: 85).

W kwietniu 1731 roku również w odległym klasztorze św. Pawła na wybrzeżu Morza Czerwonego skopiował Tourtechot kolejną, stereotypową inskrypcję (por. niżej) ${ }^{41}$.

Już w drodze powrotnej z Górnego Egiptu zatrzymał się Tourtechot 1 maja 1731 roku w Antinooupolis/Antinoe, na wschodnim brzegu

37 Zob. kolejne publikacje tej inskrypcji: Letronne 1842: 49-52; Franzius (ed.) 1853: 4716.e (tu w literaturze nie uwzględniono kopii Tourtechota); Smoleński 1910: nr I (tu także pełna rekonstrukcja tekstu).

38 Znany też był jako klasztor św. Ammoniosa (Deir Manawus), którego fundacja przypisywana jest nieraz cesarzowej Helenie. Por szczegółowy opis: Muc 2008: 207-209.

39 Por. Smoleński 1910: nr II (tu również autor prostuje mniemanie Tourtechota, który toponim podany jako „Assena” identyfikuje ze „starożytnym Syenne” (Asuanem).

40 Letronne 1842: 103-110; Franzius (ed.) 1853: 4714 (z uwzględnieniem Tourtechota); Smoleński 1910: nr III.

$41 \quad$ Tourtechot 1745: 119; zob. także przypisy 46 i 47. 
$\mathrm{Nilu}^{42}$. W odległości stu kroków od zrujnowanego łuku triumfalnego odnalazł na bazie jednej z kolumn grecką inskrypcję (il. 5) poświęconą Markowi Aureliuszowi (161-180 n.e.). Jej tekst włączył do swego opisu (Tourtechot 1745: 126), później stała się ona przedmiotem zainteresowań także innych badaczy ${ }^{43}$.

W trakcie swej podróży Tourtechot wykazał szczególne zainteresowanie koptyjskimi klasztorami. $Z$ jednej strony było to spowodowane możliwością nawiązania bliższego kontaktu z ich mieszkańcami, gdyż w jego ekipie, jak już wspomniano, znajdowało się także czterech koptyjskich duchownych. Najczęściej też u Koptów podróżująca grupa szukała spoczynku i nocnego schronienia. Na początku kwietnia 1731 roku podróżni postanowili oddalić się od Nilu i zmierzali trudnym, pustynnym szlakiem na wschód, ku wybrzeżom Morza Czerwonego. Decyzję tę podjął Tourtechot, by dotrzeć do dwóch słynnych klasztorów - św. Antoniego i św. Pawła. Ten pierwszy (Deir Anba Antunius) usytuowany jest u stóp Góry Qolzum (Clysma) ${ }^{44}$. Zgodnie $\mathrm{z}$ tradycją $\mathrm{w}$ jednej z pobliskich jaskiń zamieszkać miał około roku 312 św. Antoni, wokół którego zgromadziła się następnie grupa współbraci. W trakcie swych podróży wcześniej dotarli tu m.in. J. Wansleben (1672) oraz w kilka lat później ojciec Sicard (1711). Jak wynika z opisu Tourtechota, zdołał on poznać bliżej warunki bytowe mnichów (Tourtechot 1745: 107-114). Do obronnie usytuowanego klasztoru wciągnięty został na linie, ulokowano go w oddzielnej celi i traktowano podobnie, jak pozostałych mnichów (oznaczało to, iż rankiem i wieczorem otrzymywał, jak oni, porcję soczewicy i kawałek niezbyt dobrego chleba). W skład klasztornego zespołu, zgodnie z opisem Tourtechota, wchodziło 28 cel przyległych do refektarza, ponadto kuchnia oraz dwa małe i ciemne kościoły. Ważny element stanowiła wieża obronna, do której

42 Ar. Ansina, Szejch Abade. Zgodnie z tradycją miasto zostało założone 30 października 130 roku przez Hadriana, aby upamiętnić śmierć Antinousa, swego faworyta. Jak wykazały badania wykopaliskowe, miasto z czasów Hadriana powstało na pozostałościach starszego osadnictwa sięgającego czasów wczesnodynastycznych i Nowego Państwa.

43 Por. także Franzius (ed.) 1853: 4705 oraz Smoleński 1910: nr V. Początek niemal identycznej inskrypcji odnotował Tourtechot także na bazie innej kolumny (Tourtechot 1745: 126).

44 Por. szczegółowy opis całego zespołu: Muc 2008: 150-155. 
prowadził zwodzony most. W pomieszczeniach wieży mnisi gromadzili naczynia liturgiczne i księgi oraz zapasy żywności; tu chronili się także w czasie arabskich najazdów. Opis jest szczegółowy, obejmuje m.in. zaopatrzenie w wodę, wykaz roślin uprawianych w klasztornym ogrodzie, a także ubiór mnichów oraz porządek nabożeństw. Niestety, ogólna ocena zakonnej wspólnoty nie wypadła zbyt pochlebnie: „Mnisi są przesądni, a z tego wynika ich ignorancja. Nie sądzę, by dokładnie przestrzegali reguły, do której są zobowiązani, wstępując do zakonu. Wiem natomiast, iż większość z nich zajmuje się poszukiwaniem kamienia filozoficznego i wypisywaniem karteczek mających zwalczać choroby" (Tourtechot 1745: 113-114) ${ }^{45}$.

10 kwietnia Tourtechot wyruszył do niezbyt odległego (osiem godzin drogi), siostrzanego klasztoru św. Pawła (Deir Anba Bula), położonego jednak w miejscu bardziej odludnym ${ }^{46}$. Doznał tu podobnego przyjęcia jak w poprzednim klasztorze. Opis pozostawiony przez Tourtechota jest również i w tym przypadku cennym świadectwem obrazującym stan obiektu i życie jego mieszkańców (Tourtechot 1745: 115-121). Opisując klasztorny kościół, autor relacji odnotował ponadto i skopiował (wprawdzie dość nieudolnie) tekst inskrypcji, którą dostrzegł na jednej ze ścian ołtarza (Tourtechot 1745: 119); miał to być „napis grecki zanotowany przy użyciu starożytnych liter" (tzn. koptyjskich) ${ }^{47}$.

Już po powrocie do Kairu, pod koniec sierpnia 1731 roku, dotarł też Tourtechot do klasztorów położonych w Wadi en-Natrun: do klasztoru Syryjczyków (Deir es-Suriani) oraz do klasztoru św. Makarego (Deir Anba Makar $)^{48}$. Również i tu krótki kontakt z mnichami nie wywarł na gościu zbyt dobrego wrażenia; jak odnotował wówczas: „klasztory popadają w ruinę, kurz wżera się w manuskrypty i księgi przechowywane w bibliotekach, zaś poczciwi mnisi, którzy nie mają z nich żadnego pożytku, skłonni są raczej dopuścić do ich zagłady, niż sprzedać za przyzwoitą cenę" (Tourtechot 1745: 179-180). Mimo usilnych próśb Tourtechot nie został nawet wpuszczony do klasztornych bibliotek.

\footnotetext{
45 Owe „karteczki” to specjalnie zapisywane zaklęcia lecznicze (amulety), sprzedawane okolicznym mieszkańcom i pielgrzymom.

46 Por. szczegółowy opis zespołu: Muc 2008: 155-160.

47 Zob. uwagi Smoleńskiego na jej temat: Smoleński 1910: nr IV.

48 Zob. szczegółowy opis obu zespołów: Muc 2008: 55-60; 63-70.
} 
Jego krytyczna i w pełni uzasadniona opinia znalazła więc i w tym przypadku całkowite potwierdzenie.

W swej relacji sporo uwagi poświęcił Tourtechot szczegółom codziennej egzystencji oraz obserwacjom przyrodniczym ${ }^{49}$ i obyczajowym. W jego opisie nie brak też momentów groźnych, a także swoistych ciekawostek, które jego dość prostą i bezstronną relację nieco ubarwiają, przyciągając tym samym uwagę czytelnika. Moment bez wątpienia istotny stanowił pobyt w Edfu, gdzie wobec zaistniałych zagrożeń podjąć musiał decyzję o zakończeniu dalszego marszu na południe, w górę Nilu (por. wyżej). Przeżył też groźne chwile, gdy w Fajum nad jeziorem Moeris osaczony został przez kilku tubylców z workami, łudzących się nadzieją, że napełnią je złotem, które zamierzali mu odebrać (Tourtechot 1745: 162-164). Byli bowiem przekonani, iż mają do czynienia z wielkim czarownikiem posiadającym moc ,„przyciągania" skarbów (wspomagać ją miała niewielka szkatułka z ukrytym w jej wnętrzu niewielkim kółkiem). Uratował go z opresji miejscowy kadi, który rozumiejąc istotę działania busoli, przepędził jego prześladowców.

Szczególny fragment omawianego tekstu stanowi rozdział XVIII, ostatni, pt. „O sposobie wykluwania się kur, kaczek i gęsi” (Tourtechot 1745: 257-262). Autor omawia w nim zadziwiający Europejczyków, nieznany im sposób konstruowania specjalnych ,pieców”, czyli sztucznych wylęgarni drobiu w Egipcie stosowanych od wieków ${ }^{50}$.

[Zasługi Tourtechota - Grangera upamiętniono we Francji jeszcze w XVIII stuleciu, wprowadzając do nazewnictwa botanicznego na oznaczenie jednej z egzotycznych roślin pochodzącej z wysp Oceanu Indyjskiego (z rodziny Chrysobalanaceae) nazwę „grangeria"51].

49 Rozdziały poświęcone wydobyciu natronu i pustynnym skamielinom (IX), egipskiej faunie i florze (XIV), nadto irygacji (XV) oraz formom sprawowania władzy (XIII).

50 Opisy rozmaitych egipskich inkubatorów spotykamy w wielu sprawozdaniach z podróży do Egiptu; jeden z najwcześniejszych pochodzi z relacji Mikołaja Krzysztofa Radziwiłła „Sierotki” (1583). Zob. Śliwa 2012: 389-393 (rozdział Relationes curiosae). ${ }^{51}$ Nazwę tę roślinie wyhodowanej z nasion uzyskanych przez paryski Ogród Botaniczny w latach 1733-1736 nadał Antoine Laurent de Jussieu (por. jego Genera plantarum secundum ordines naturales disposita, juxta methodum in Horto regio parisiensi exaratam, anno 1774, Paris 1789, s. 340). 


\section{ILUSTRACJE}

1. Teby Zachodnie. Na wprost nekropola Szejch Abd el-Gurna; na pierwszym planie u dołu Kolosy Memnona; z prawej Ramesseum, z lewej Medinet Habu (R. Pococke, Observations on Egypt, London 1743).

2. Luksor. Widok pylonów świątyni Amona, obelisków i kolosalnych posągów Ramzesa II przysypanych pustynnym piaskiem (F.L. Norden, Travels in Egypt and in Nubia, London 1751).

3. Nicolas Tourtechot/Sieur Granger, Relation du voyage fait en Égypte, Paris 1745. Strona tytułowa.

4. Inskrypcja grecka skopiowana przez N. Tourtechota w Qus/Apollinopolis parva w roku 1731 (Relation du voyage fait en Égypte, Paris 1745, s. 54).

5. Inskrypcja grecka skopiowana przez N. Tourtechota w Szejch Abade/Antinooupolis w roku 1731 (Relation du voyage fait en Égypte, Paris 1745, s. 126).

\section{BIBLIOGRAFIA}

\section{Źródła}

Bruce J., 1790, Travels to discover the source of the Nile [...], vol. 1-5, London. Denon D. V., 1802, Voyage dans la Basse et la Haute Égypte, Paris.

Franzius I. (ed.), 1853, Corpus Inscriptionum Graecarum. Auctoritate et impensis Academiae Litterarum Regiae Borussicae ex materia collecto ab Augusto Boeckhio Academiae socio, vol. 3, pars 29, Inscriptiones Aegypti, Berolini.

Letronne J. A., 1842, Recueil des inscriptions grecques et latines d'Égypte, vol. 1 , Paris.

Letronne J. A., 1848, Recueil des inscriptions grecques et latines d'Égypte, vol. 2, Paris.

Lucas P., 1704, Voyage du Sieur Paul Lucas au Levant. On y trouvera entr'autre une description de la Haute Égypte, suivant le cours du Nil, depuis le Caire jusques aux Cataractes, avec une Carte exacte de ce fleuve, que personne n'avoit donnée, vol. 1-2, Paris.

Lucas P., 1720, Voyage du Sieur Paul Lucas fait en 1714 [...] dans la Turquie, l'Asie, Sourie, Haute et Basse-Égypte etc., vol. 1-3, Amsterdam.

Norden F. L., 1755, Travels in Egypt and Nubia, London.

Pococke R., 1743-1745, A Description of the East, and some other countries, vol. 1-2, London. 
Radziwiłł M. K., 1962, Podróż do Ziemi Świętej, Syrii i Egiptu 1582-1584, oprac. L. Kukulski, Warszawa.

Sicard C., 1982, Oeuvres, vol. 1-3, Le Caire.

Thévenot M., 1681, Recueil du voyages, Paris.

Tourtechot N., 1745, Relation du voyage fait en Égypte, par le Sieur Granger, en l'année 1730. Ou l'on voit ce qu'il y a de plus remarquable, particulièrement sur l'histore naturelle, Paris.

Tourtechot N., 1751, Des Herrn Grangers Beschreibung sejner in dem Jahre 1730 durch Egypten gethanen Reisse, vorin das merkvurdigste in diesem Lande, insonderheit was die Naturgeschichte betrifft, beschrieben ist, [w:] Sammlung aller Reisen, Theil 3, Göttingen, s. 307-428.

Tourtechot N., 1773, A Journey through Egypt made in the year 1730, in which there are to be found the most remarkable particulars on Natural History, transl. J. R. Forster, London.

Wansleben J. M., 1677, Nouvelle relations en forme de journal d'un voyage fait en Égypte par le P. Vansleb religieux dominicain en 1672 et 1673, Paris.

\section{Opracowania}

Bierbrier M. L. (red.), 2012, Who Was Who in Egyptology, London.

Bret P., 2002, Egipt w czasach Napoleona, przeł. R. Wilgosiewicz-Skutecka, Poznań.

Chabot J. B., 1897, 'N. Tourtechot, Les ruines de Palmyre en 1735', Journal Asiatique, s. 335-355.

Dictionnaire de biographie française, 1985, vol. 16, Paris 1985.

Greener L., 1966, The discovery of Egypt, London 1966.

Lamy F. i Bruwier M.-C., 2005, L'Égyptologie avant Champollion, Louvain-la-Neuve.

Muc A., 2008, Architektura monastyczna na terenie Egiptu, Kraków.

Smoleński T., 1910, 'Les inscriptions grecques du Sieur Granger', Bulletin de la Societé Archéologique d'Alexandrie 12, Nouvelle Série 3/1, s. 27-33.

Solé R., 2001, Uczeni Bonapartego, przeł. J. Kozłowska, Warszawa.

Strathern P., 2009, Napoleon w Egipcie. „Największa sława”, przeł. T. Hornowski, Poznań.

Śliwa J., 2012, Badacze, kolekcjonerzy, podróżnicy, Kraków.

Śliwa J., Zinkow L. (oprac.), 2010, Tadeusz Smoleński 1884-1909. Pisma naukowe i publicystyczne, Kraków. 


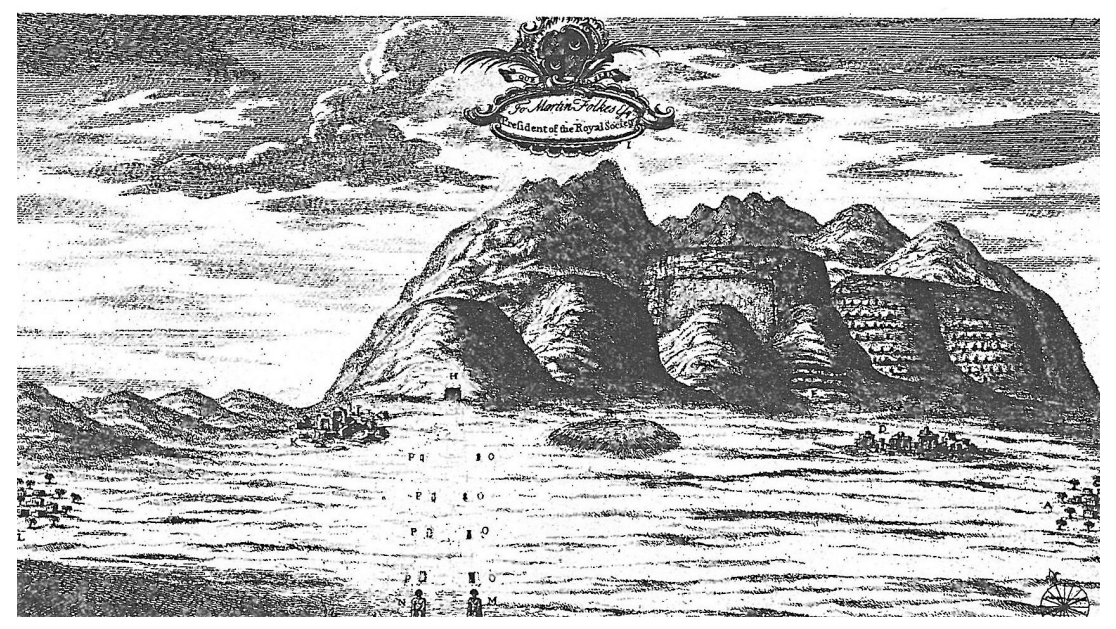

1. Teby Zachodnie. Na wprost nekropola Szejch Abd el-Gurna; na pierwszym planie u dołu Kolosy Memnona; z prawej Ramesseum, z lewej Medinet Habu.

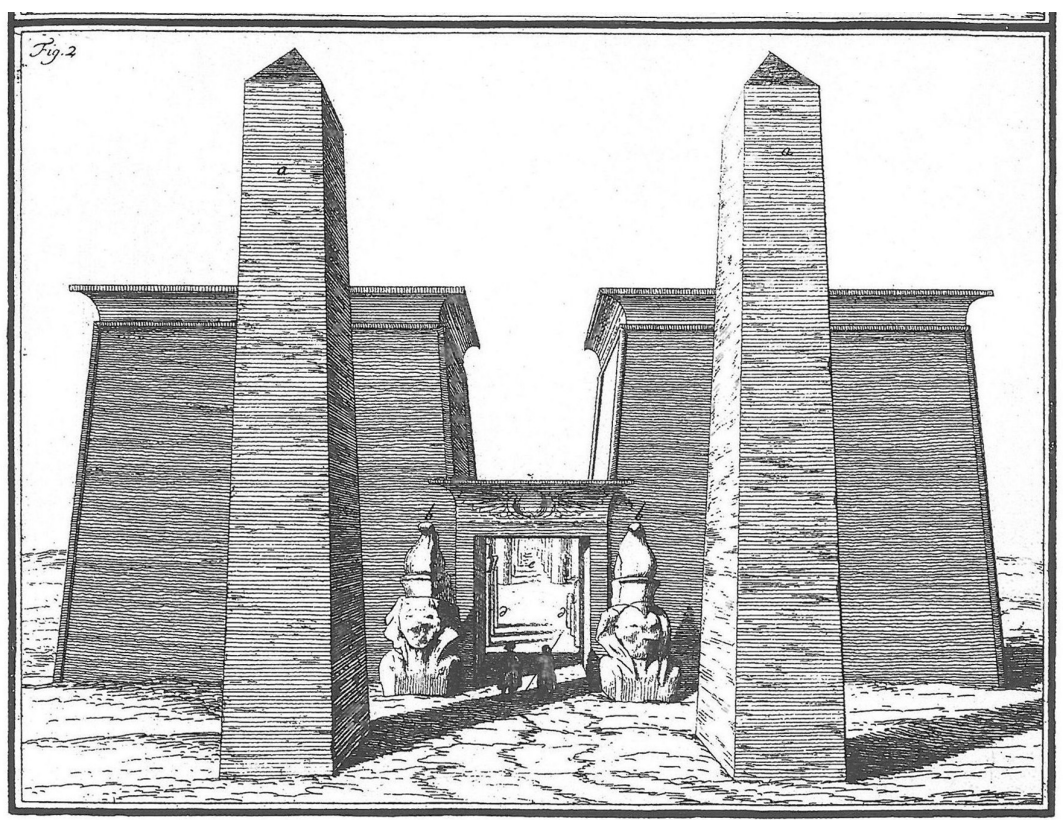

2. Luksor. Widok pylonów świątyni Amona, obelisków i kolosalnych posągów Ramzesa II przysypanych pustynnym piaskiem. 


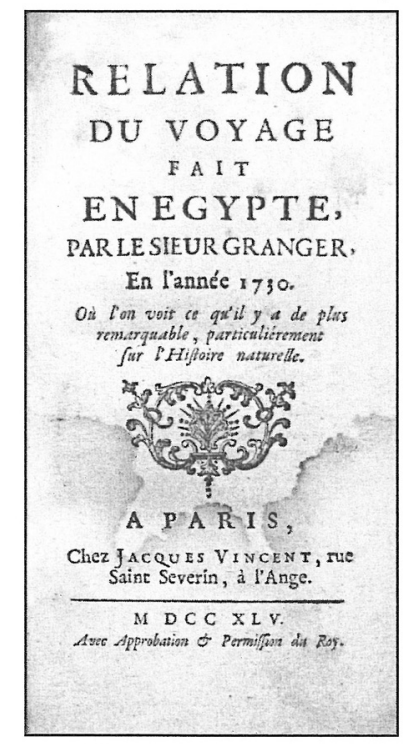

3. Nicolas Tourtechot/Sieur Granger, Relation du voyage fait en Égypte, Paris 1745.

Strona tytułowa.

$$
\begin{aligned}
& \text { 54 VOTAGE } \\
& \Sigma I \Lambda I \Sigma \Sigma A K A E O \text {. IA- } \\
& \text { IPAKI.BA } \Sigma I \triangle E \Upsilon \Sigma \text {. } \\
& \text { ПTO } \triangle \mathrm{EMAIO \Sigma} \\
& \text { OEOIME. ГAAOI. } \\
& \text { ФI OMHTOPE } \Sigma \text {. } \\
& \text { E П } \Sigma \text { T } \Omega \text { KAITOI }
\end{aligned}
$$

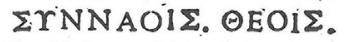

$$
\begin{aligned}
& \text { De Kous on va à Luxor } \\
& \text { qui en eft éloigné de fept } \\
& \text { lieuës: Ce village elt bấti. } \\
& \text { fur les ruines de Thebes. } \\
& \text { cette ancienne ville fi fus } \\
& \text { perbe parfes édifices, n'of- } \\
& \text { fre plus aujourd'hui à la } \\
& \text { vûe que des tas de pierres. } \\
& \text { La premiere chofe qui fe }
\end{aligned}
$$

26 V O Y TE

ATA@HI TrXHI.

MOKPATOPIKI $\dot{\Sigma} \triangle P I$ MAOK $\Omega I A \Upsilon \Upsilon H \triangle I K$ 。

Auprès de cette colonne on voit le pied d'etal d'une autre colonne fur lequel il y a cetre autre Infcription.

$$
\text { ATAOHI...TYHL。 }
$$

AYKOKPATOPKAI EAPI.

MAPK: $\Omega I \triangle Y$. . . PHAI-

SISE OTHPSI $\triangle A E T A-$ PHETLEPEIETT. TXEI: MHRPIATNYPAHTTH.

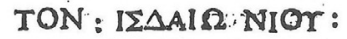
$\triangle I A M O N L L:$ EXT $\Omega$ : NO. IMANIOEAT $\Omega N O H$.

4. Inskrypcja grecka skopiowana przez 5. Inskrypcja grecka skopiowana przez N. Tourtechota w Qus/Apollinopolis parva w roku 1731.

N. Tourtechota w Szejch Abade/ Antinooupolis w roku 1731. 